\title{
DELINEATION OF GLACIER DRAINAGE BASINS ON WESTERN VATNAJOKULL
}

\author{
by
}

\author{
Helgi Björnsson
}

(Science Institute, University of Iceland, Dunhagi 3, Reykjavik, Iceland)

\section{ABSTRACT}

Three ice-drainage basins on western Vatnajökull have been delineated with the aid of the first available, accurate ice-surface maps. These basins drain ice towards the major river systems: Tungnaá, Sylgja, and Kaldakvisl. There seems to be an important difference in the location of ice-drainage basins and melt water-drainage basins for the rivers Tungnaá and Sylgja. This is due to the influence of the bedrock topography on the flow of basal water.

\section{INTRODUCTION}

The glacier surface elevation and the bedrock topography of western Vatnajökull has been mapped in detail by radio echo-soundings (Björnsson, in press). The accurate surface-elevation maps allow delineation of the individual ice catchment basins, on a regional scale. The bedrock maps make possible studies of the influence of bedrock topography on the drainage of the melt water that enters the glacier bed through moulins, crevasses, and veins, as well as basal meltwater, produced by frictional and geothermal heat. The delineation of the watersheds on ice caps, which drain melt water to many rivers, is an important topic of applied glaciology in Iceland. The paper considers the drainage basins for three rivers which drain western Vatnajökull: Tungnaá, Sylgja and Kaldakvisl (Fig.1).

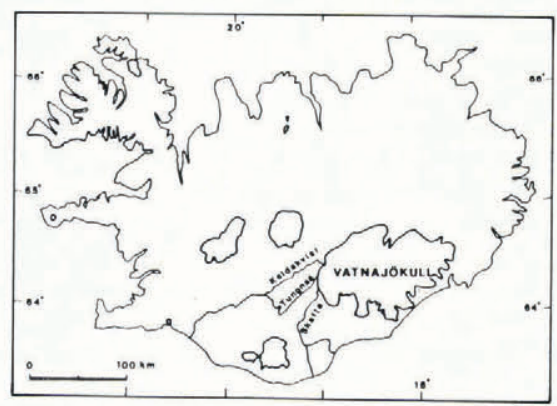

Fig.1. Location map of ice caps and the main river systems from western Vatnajökull.

\section{DELINEATION OF ICE FLOW BASINS}

Fig. 2 shows the boundaries of the ice catchment basins for three of the main river systems originating on western Vatnajökull, separated on the basis of ice flow on a regional scale. The flow lines are drawn perpendicular to smoothed elevation contours, eliminating the relatively local, detailed deviations in the surface slopes because of ice flow over irregularities in the bed. Following Budd $(1968,1970)$ and Robin (1967), we assume that the mean movement of the ice follows the direction of, the mean, maximum, surface slopes, averaged over the distances that are an order of magnitude greater than the ice thickness (i.e. $2-5 \mathrm{~km}$ in the present case. This was done manually). The boundaries of the catchment areas were drawn upstream from the edge to the highest point. It is assumed that the location of the central flow divide corresponds to the

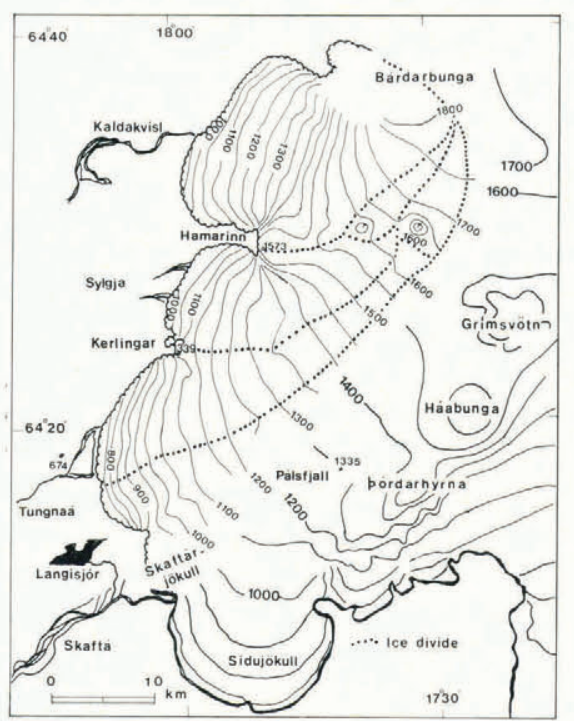

Fig.2. The main ice catchment basins of western Vatnajökull. The basins drain ice towards the rivers Tungnaá, Sylgja and Kaldakvisl. Further, the catchment basins of two ice cauldrons are delineated.

highest part of the ice surface and that the ice flow, at depth, is not controlled by the bedrock slope.

The outlets Tungnaárjökull and Skaftárjökull (named after the rivers) are separated by an ice divide which lies to the NE of Tungnaárjökull and terminates SW of a catchment basin which drains ice towards an ice cauldron, an almost circular depression in the ice surface (Fig.3). The ice cauldron is situated above a subglacial, geothermal area,

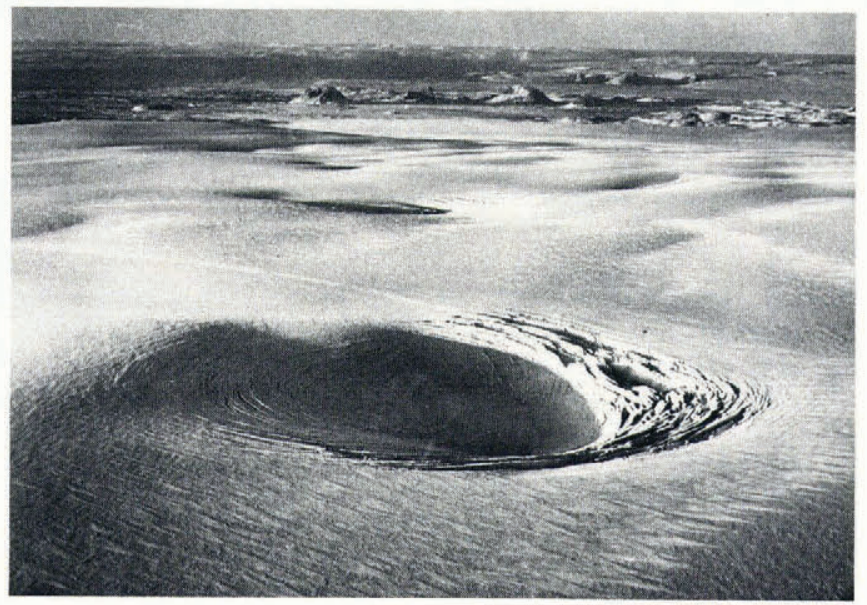

Fig.3. An ice cauldron $10 \mathrm{~km}$ NW of Grimsvötn, Vatnajökull, Iceland. Diameter: $3 \mathrm{~km}$. Maximum depth: $150 \mathrm{~m}$. Photograph: Helgi Björnsson, 8th January 1982, at the end of a jökulhlaup in the river Skaftá. 
where melt water is continuously produced, but trapped and accumulated in a subglacial lake. Ice flows continuously into the depression, but, before it is eliminated, the subglacia water escapes along the bed in a jökulhlaup (Björnsson 1975). The area of Tungnaárjökull catchment basin is about $195 \mathrm{~km}^{2}$, but $40 \mathrm{~km}^{2}$ for the ice cauldron. The catchment basin for Sylgjujökull (area $165 \mathrm{~km}^{2}$ ) terminates SW of another ice cauldron, about $30 \mathrm{~km}^{2}$ in area. The northernmost catchment basin, Köldukvíslarjökull, drains water to the river Kaldakvisl.

\section{DELINEATION OF WATER FLOW BASINS}

The routes of water flow on western Vatnajökull have not so far been studied by tracer experiments, but the jökulhlaups from the two ice cauldrons, north-west of Grímsvötn, provide information on subglacial watercourses. The cauldrons drain across the ice divides to the ice catchment basins of Tungnaá and Sylgja, respectively, as one would expect, looking at the general ice-surface slope in Fig.2. But the water does not drain to the rivers Tungnaá and Sylgja. Both cauldrons drain water to the river Skaftá. During the jökulhlaups, the flood water emerges at the glacier terminus near Langisjor (Fig.2). Hence, the water must have flowed down the valley, east of the subglacial ridge that strikes SW from Hamarinn towards Fögrufjöll (Fig.4). Further, the water must have

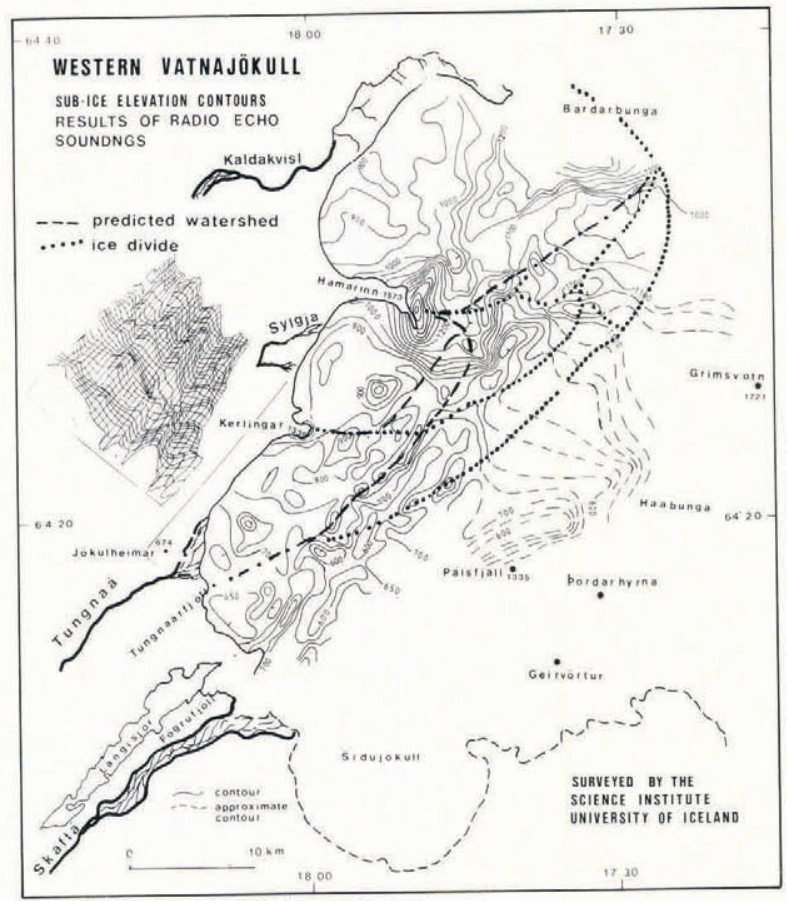

Fig.4. Predicted location of watersheds and ice divides on western Vatnajökull, drawn on a map showing the bedrock topography (Björnsson in press). The basins drain melt water to the rivers Tungnaá, Sylgja and Kaldakvisl. The ice cauldrons drain water to Skaftá.

flowed north-west through the pass in the ridge, north-east of Langisjor $\left(64^{\circ} 18^{\prime} \mathrm{N}, 18^{\circ} 00^{\prime} \mathrm{W}\right)$. These observations indicate that the water divide, during the jökulhlaups, is located on the above-mentioned subglacial ridge from Hamarinn towards the pass. From there, the watershed trends towards Tungnaárfjöll (Fig.3). Such a location of the watersheds can be predicted by a theory of water-filled, subglacial conduits (Shreve 1972, Röthlisberger 1972), in which the water pressure $\left(p_{w}\right)$ is assumed to equal the ice overburden pressure, minus a constant (or a negligible) deviation, due to effects of irregularities in the bedrock and the conduits' strength counteracting the ice overburden pressure.

The watershed is located where the gradient is zero $(\nabla \phi$ $=0)$ for the potential $\phi=\rho_{\mathrm{w}} \mathrm{g} \mathrm{Z}_{\mathrm{b}}+\mathrm{p}_{\mathrm{w}}$ which drives water along the bed. The gradient in the direction of water flow is the sum of two gradient vectors.

$$
\nabla \phi_{\mathrm{b}}=\left(\left(\rho_{\mathrm{w}}-\rho_{\mathrm{i}}\right) \mathrm{g} \nabla \mathrm{Z}_{\mathrm{b}}+\mathrm{g} \rho_{\mathrm{i}} \nabla \mathrm{Z}_{\mathrm{s}}\right) \cos \alpha
$$

The symbol $\rho_{\mathrm{w}}$ represents the density of water, $\rho_{\mathrm{i}}$ the density of ice, $\mathrm{g}$ is the acceleration of gravity, and $\mathrm{Z}_{\mathrm{b}}$ and $\mathrm{Z}_{\mathrm{S}}$ are the elevations of the glacier bed and surface, respectively, relative to a horizontal datum level, which is placed at the elevation where the glacial river emerges at the glacier snout.

The first vector is normal to the contour lines of the glacier bed; the other normal to the contours of the upper glacier surface. For slowly varying bedrock, $\cos \alpha \approx 1$; $\alpha$ being the slope of the bed. Water flow in an isotope basal layer would point perpendicular to the potential lines. This model of the basal water flow is a first-order approximation and does not describe details in the water flow. In the present paper, we map the location for which $\nabla \rho=0$.

Figure 3 shows the predicted location of the watersheds, on a regional scale, on western Vatnajökull. The water divide between Tungnaá and Skaftá would lie upstream from Tungnaárfjöll on the subglacial ridge which trends towards Hamarinn. The local gradient in the ice overburden pressure would tend to drive water straight into the pass and not further south-westwards in the valley east of the subglacial ridge (Fig.2 and 4). The area of the water-drainage basin for Tungnaá is estimated to be about $130 \mathrm{~km}^{2}$, i.e. $65 \mathrm{~km}^{2}$ less than that of the ice-drainage basin. The predicted water-drainage basin for the river Sylgja is $95 \mathrm{~km}^{2}$, compared with $165 \mathrm{~km}^{2}$ for the ice catchment basin. For Kaldakvisl, both basins are equal, at about $300 \mathrm{~km}^{2}$.

\section{DISCUSSION}

The location of the watersheds predicted by this theory (eq.1) may only apply for conditions during jökulhlaups. However, the drainage of jökulhlaups through the pass may indicate the existence of subglacial watercourses through the pass before the start of jökulhlaups and the existing channels, rather than new ones, are further developed as routes of the jökulhaup. Furthermore, if subglacial watercourses normally transport water through the pass, the local water pressure must be close to the ice overburden pressure. The average bedrock slope, upwards from the pass, is about $8^{\circ}$ and the water would be drained by an ice surface slope of $1^{\circ}$ (Figs. 2 and 3 , cfr. eql).

Improved models of the drainage of basal water would include the effects of fluctuations (annual) in the pressure, due to variations in the supply of water. Further, the assumption of water-filled conduits may not apply near the edge and on the steepest slopes, where melting by frictional heat is high (see Lliboutry 1983, Hooke 1984). Then, the actual water pressure would be atmospheric (or that of the triple point) and the flow of water would be dominated by the bedrock topography. In that case, the water divide would be located at the ridge separating the rivers Skafta and Tungnaá, at least as far as the pass. It is more questionable whether water would flow into the pass or continue south-westwards in the valley. Further studies on that problem may require more detailed radio echo-soundings.

Finally, the assumption of an impermeable bedrock may not be realistic in glaciers where the bedrock consists of hyaloclastics. However, we may argue that the major water volumes flow along the ice-rock interface, where the hydraulic conductivity is higher than in the subglacial aquifer. Further, the flow of water in the subglacial aquifer depends on the ice thickness, although it is not forced to follow the details in the bed. Some water may drain down through a porous bedrock and, as groundwater, to the lowland outside the glacier.

\section{CONCLUSIONS}

The paper reports significant differences in the location of ice-drainage basins and water-drainage basins of rivers from western Vatnajökull. This is due to the influence of the bedrock topography on the flow of basal water. This 
applies for conditions during jökulhlaups and can be predicted by a theory of basal water flow in water-filled conduits. The predictions should be tested for conditions not affected by jökulhlaups and models derived for variable water pressure. In more realistic models, however, the basal water-drainage is expected to be still more influenced by the bedrock topography.

\section{REFERENCES}

Björnsson H 1975 Subglacial water reservoirs, jökulhlaups and volcanic eruptions. Jökull 25: 1-14

Björnsson H 1986 Surface and bedrock topography of icecaps in Iceland mapped by radio echo soundings. Annals of Glaciology 8

Budd W F 1968 The longitudinal velocity profile of large ice masses. International Association of Scientific Hydrology Publication 79 (General Assembly of Bern 1967 - Snow and Ice): 58-77

Budd W F 1970 Ice flow over bedrock perturbations. Journal of Glaciology 9(55): 29-48

Hooke R L 1984 On the role of mechanical energy in maintaining subglacial water conduits at atmospheric pressure. Journal of Glaciology 30(105): 180-187

Lliboutry L 1983 Modifications to the theory of intraglacial waterways for the case of subglacial ones. Journal of Glaciology 29(102): 216-226

Robin G de Q 1967 Surface topography of ice sheets. Nature 215(5105): 1029-1032

Röthlisberger H 1972 Water pressure in intra- and subglacial channels. Journal of Glaciology 11(62): 177-203

Shreve R L 1972 Movement of water in glaciers. Journal of Glaciology 11(62): 205-214 